\title{
LAZARENKOA, A NEW MOSS GENUS FROM THE RUSSIAN FAR EAST
} LAZARENKOA, НОВЫЙ РОД МХОВ С РОССИЙСКОГО ДАЛЬНЕГО ВОСТОКА

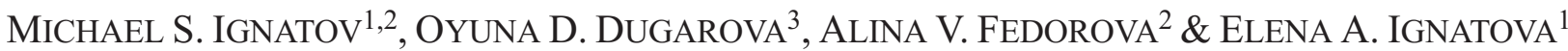 \\ МИХАИЛ С. ИГНАТОВ ${ }^{1,2}$, ОЮНА Д. ДУГАРОВА $^{3}$, АЛИНА В. ФЕДОРОВА $^{2}$, ЕЛЕНА А. ИГНАТОВА $^{1}$
}

Abstract

\begin{abstract}
A very small pleurocarpous moss recently collected in a limestome area in the Russian Far East, Lozovyj Range, was found in a molecular phylogeny to be a member of the complex of genera commonly referred to Leskeaceae or Thuidiaceae. Chloroplastic $\operatorname{rn} \mathrm{L}-\mathrm{F}$ data (low variable dataset) found its closest relationship with South Chinese Leskea scabrinervis. Nuclear ITS sequences (much more variable dataset) did not confirm this. Morphology is in a higher consistence with the signal from the $\operatorname{trn} \mathrm{L}-\mathrm{F}$ region, although the similarity of Russian Far Eastern plants with South Chinese ones is not full. Even if these plants are congeneric, their position in the genus Leskea contradicts the obtained phylogeny, and there is no other genera in Leskeaceae to place them. Therefore, Far Eastern plant is described as a new species and referred to a new genus Lazarenkoa. We refrain to refer Leskea scabrinervis to this new genus until more studies of that rare species appear. The occurrence of Lazarenkoa in the Lozovyj Range once again points the urgent need of its conservational value: in this small area are concentrated the only (or one of two) Russian populations of Homaliadelphus targionianus, Enrothia polyclada, Miyabaea fruticella, Forsstroemia noguchiana, Fissidens hyalinus, F. beckettii, and Ephemerum spinifolium.
\end{abstract}

Резюме

Бокоплодный мох очень маленького размера, недавно собранный в известняковом районе на российском Дальнем Востоке - Лозовом хребте, согласно молекулярно-филогенетическим данным относится к комплексу родов, традиционно помещаемых в Leskeaceae или Thuidiaceae. Хлоропластные последовательности $t r n \mathrm{~L}-\mathrm{F}$ (мало вариабельный маркер) указывают на близкое родство с описанной из Китая Leskea scabrinervis, однако данные по ядерному маркеру ITS (более вариабельные последовательности) это родство не подтверждают. Морфологические признаки в большей степени соответствуют сигналу от участка $t r n \mathrm{~L}-\mathrm{F}$, однако сходство между растениями с российского Дальнего Востока и из Южного Китая не является полным. Даже если эти растения относятся к одному роду, их нельзя относить к роду Leskea, поскольку это противоречит полученной филогенетической реконструкции, и, в то же время, в Leskeaceae нет никакого другого рода, в который бы можно было их поместить. Поэтому дальневосточные растения мы описываем как новый вид, относящийся к новому роду Lazarenkoa. Мы предпочитаем не относить Leskea scabrinervis к этому новому роду до тех пор, пока образцы этого редкого вида не будут дополнительно изучены. Произрастание Lazarenkoa на Лозовом хребте еще раз указывает на срочную необходимость охраны этой территории: здесь на небольшой площади сконцентрированы единственные в России популяции Homaliadelphus targionianus (или одна из двух), Enrothia polyclada, Miyabaea fruticella, Forsstroemia noguchiana, Fissidens hyalinus, F. beckettii и Ephemerum spinifolium.

KEYWORDS: mosses, taxonomy, molecular phylogenetic reconstructions, new species, Russia

\section{INTRODUCTION}

The moss flora of the continental part of the Russian Far East was studied and comprehensively overviewed three times: by Lazarenko (1940-1945), Bardunov \& Cherdantseva (1982) and Cherdantseva et al. (2018). Despite the latter publication provided a comprehensive synthesis of a great buck of information, the revision of new and old "difficult" collections, especially applying molecular mark- ers, still continues to bring interesting findings, and the present paper is focused on one of such specimens.

It was collected by one of the co-authors, OD, in Lozovyj Range, one of few calcareous areas in the southern Russian Far East, where the only (or one of two) Russian populations of such rare southern species as Homaliadelphus targionianus, Enrothia polyclada, Miyabaea fruticella, Forsstroemia noguchiana, Fissidens hyalinus, F.

1 - Lomonosov Moscow State University, Faculty of Biology, Plant Ecology and Geography Dept., Leninskie Gory Str. 1-12, Moscow 119234 Russia; e-mails: misha ignatov@list.ru; arctoa@list.ru

2 - Tsitsin Main Botanical Garden, Russian Academy of Sciences, Botanicheskaya Str., 4, Moscow 127276 Russia - Pосcия 127276 Москва, Ботаническая 4, ГБС РАН; e-mail: alina 77777@mail.ru

3 - Institute of General and Experimental Biology SD RAS, Sakhjanovoy str., 6, Ulan-Ude 670047 Russia; e-mail: otumurova@list.ru 
beckettii, and Ephemerum spinifolium are known. The publication on the latter species (Ignatov et al., 2013) provided overall illustrations of the area, although habitats of Ephemerum spinifolium were different. The Far Eastern moss discussed in the present paper grows on shaded limestones. Superficially it looks like a very small Pseudoleskeella, dark-green to blackish, in fine, somewhat fragile mat. As its morphology did not fit any moss known from Russia and its immediate proximity, so the study of the variable DNA loci were involved in hope to find its closest relatives.

\section{MATERIAL AND METHODS}

The specimen in question was studied by a standard protocol used is similar studies. Total genomic DNA was extracted from dry plants using the Nucleospin Plant Extraction Kit (Macherey-Nagel, Germany). Laboratory protocol was essentially the same as in previous moss studies, described in detail by, e.g., Gardiner et al. (2005).

Species for the analysed dataset were selected using BLAST resource of GenBank and from our previous datasets on Leskeaceae (as soon as it became clear that the plant belongs to this group in a broad circumscription).

Sequences were aligned by Clustal and modified manually using BioEdit 7.0 (Hall, 1999). Bayesian analysis of the ITS dataset was conducted in MrBayes (Huelsenbeck \& Ronquist, 2001) using the GTR+G model. It was run for 5000000 generations with sampling every 1000 generations. The first $25 \%$ of sampled trees were discarded for the burn-in. Supplementary maximum parsimony analysis was performed in Nona (Goloboff, 1994) in Winclada shell (Nixon, 1999), with bootstrap calculation for 1000 replications ( $\mathrm{N}$ searches 100, starting trees per repetition 100 , max trees 100 , do max), while for consensus tree parameter were: Max tree to hold 100000 , number of replications 1000 , starting tree per replication 1000 .

\section{RESULTS}

The obtained results found a controversial position of the studied Far Eastern moss.

The Bayesian analysis of the concatenated dataset found Far Eastern moss with Leskea scabrinervis in a low supported $(\mathrm{PP}=0.59)$ clade nested within in wide polytomy of various representatives of Leskeaceae and Thuidiaceae (Fig. 1).

Bayesian analysis of ITS alone (Fig. 3) placed Far Eastern plant in sister position to Thuidium +Pelekium clade $(\mathrm{PP}=1)$, but the support of their mutual clade is quite moderate $(\mathrm{PP}=0.86)$.

Bayesian analysis of $\operatorname{trn} \mathrm{L}-\mathrm{F}$ alone (Fig. 2) resolved the clade of our Far Eastern moss and Leskea scabrinervis with $\mathrm{PP}=0.96$. In some preliminary tests (not shown) with $2-$ 3 representatives of the genus Leskea, the support of Far Eastern moss+Leskea scabrinervis-clade was even maximal and then their clade was sister of Boulaya mittenii, although with only very low support.
MP analysis also found our Far Eastern moss in a sister position with Leskea scabrinervis for both concatenated dataset and for trnL-F, as it is seen in strict consensus trees. Strict consensus tree for ITS dataset resolved it not close to Leskea scabrinervis, but in a subclade of Pelekium and Thuidium, while Leskea scabrinervis in ITS tree formed a clade with Pseudoleskeopsis zippelii. Bootstrap tree from the Nona MP analysis of concatenated dataset left Far Eastern moss in almost totally unresolved polytomy of Leskeaceae and Thuidiaceae.

\section{DISCUSSION}

The present data revealed an incongruence between tree topologies inferred from ITS and $\operatorname{trn} \mathrm{L}-\mathrm{F}$ markers. The following conclusions can be inferred from the available results:

1) The affinity of the Russian Far Eastern moss in question with a South-East Chinese plant Leskea scabrinervis is rather highly supported by the $\operatorname{tr} n \mathrm{~L}-\mathrm{F}$ data, and this is congruent with morphology to a certain extent.

2) The considerable difference in ITS likely indicates that the Russian Far Eastern plant is at least not conspecific with Leskea scabrinervis in addition to their morphological distinction discussed below.

3) Regardless the interrelation of the Russian Far Eastern moss with Leskea scabrinervis, both of them do not belong to the genus Leskea and by this reason the new moss genus is proposed below.

\section{TAXONOMY}

\section{Lazarenkoa Ignatov \& Ignatova, gen. nov.}

Etymology: in honour of Soviet/Ukrainian bryologist Andrej S. Lazarenko, who provided the first comprehensive annotated catalogue of the Soviet/Russian Far East.

Type: Lazarenkoa microphylla Ignatov \& Ignatova.

Diagnosis: Plants very small. Leaves shorter than 0.5 $\mathrm{mm}$, ovate-lanceolate to narrow-triangular, with broad costa extending to ca. 0.9 the leaf length. Lamina cells thick-walled, round to oblate, somewhat bulging abaxially, so leaf dorsal side at lateral view looks rough.

Lazarenkoa microphylla Ignatov \& Ignatova, sp. nova

Figs. 4-5

Etymology: species epithet means small leaves.

Type: Primorsky Territory, Partizansk District, Nakhodka City surroundings, foothills of the Lozovyj Range (former Chandolaz), E-facing slope, or rocks in streamlet bed. $43^{\circ} 00 ' 51.1^{\prime \prime} \mathrm{N}, 133^{\circ} 01^{\prime} 13.6^{\prime \prime} \mathrm{E}, 240 \mathrm{~m}$ alt. 21.09.2015, Coll. O.D. Tumurova VL-1-14 (holotype MHA; isotype: UUH).

Description: Plants tiny, dark green, dull, in prostrate tufts. Stems creeping, up to $7 \mathrm{~mm}$ long, irregularly or subpinnately branched; branches to $2 \mathrm{~mm}$ long, patent upward; paraphyllia absent. Stem leaves appressed when dry, erectopatent when moist, ovate-lanceolate to triangular, $0.25-0.35 \times 0.1-0.15 \mathrm{~mm}$, plane; branch leaves shorter and relatively broader, ovate-triangular, 0.10 


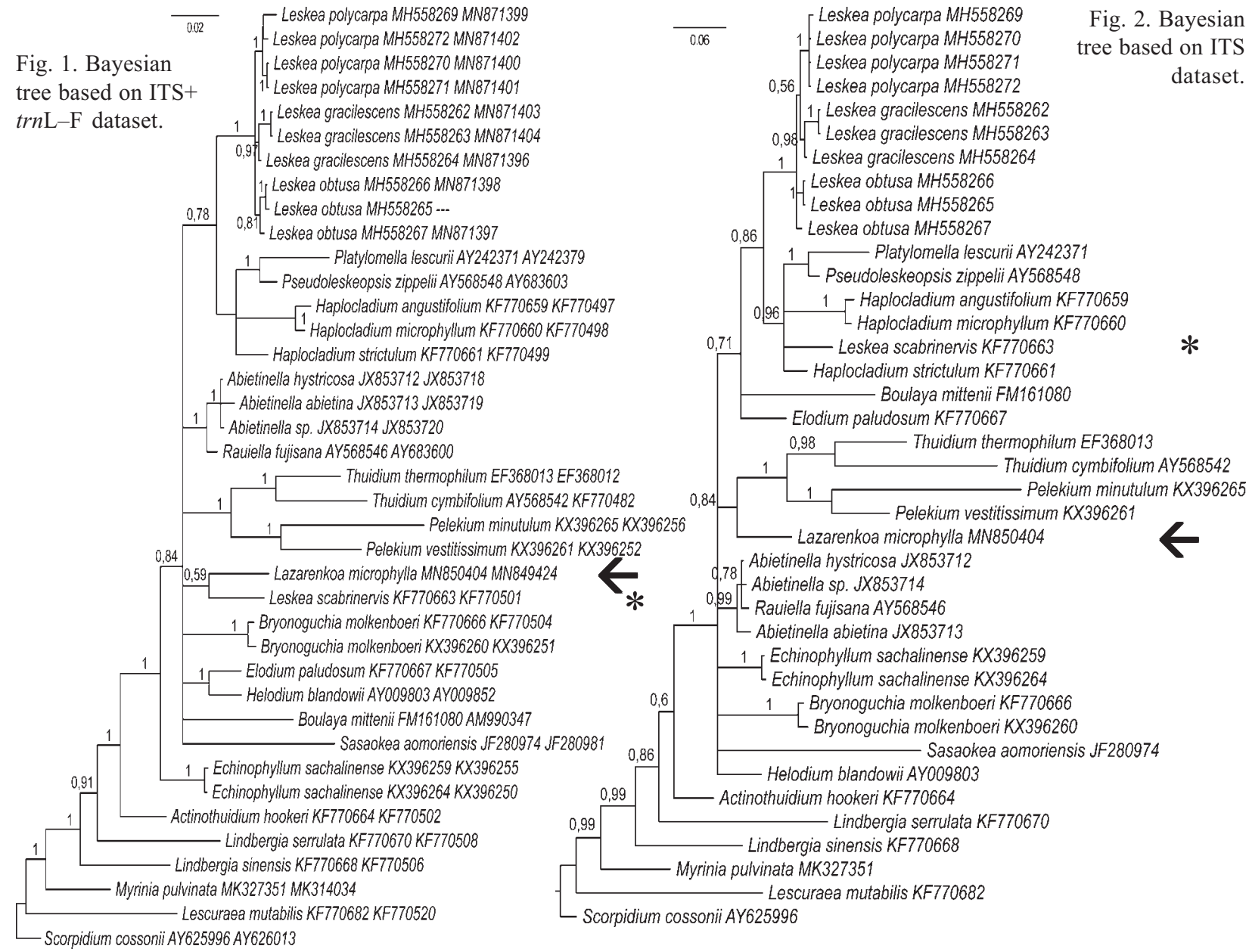

Fig. 2. Bayesian dataset. tree based on ITS Leskea graclescens Leskea gracilescens MH558263 MN871404

Leskea gracilescens MH558264 Leskea obtusa MH558266 Leskea obtusa MH558267

0,B L Leskea obtusa MH558267 MN871397 Platylomelia lescurii AY242371 AY24237 1 Haplocladium microphyllum KF770660 KF770498 Corictulum KF770661 KF770499

L Ravialla fuijsana AY568546 AY683600

1 Thuidium thermophilum EF368013 EF368012 Ium Ar568542 KF-770482 $\times 396265 \times \times 396256$

JF280981 Lazarenkoa microphylla MN850404

\section{Fig. 3. Bayesian tree} based on $\operatorname{trn} \mathrm{L}-\mathrm{F}$ dataset. Posterior probabilities are shown at branches (as in Fig. 1 and 2). Compare position of Lazarenkoa in three tress (arrowed), in relation to Leskea scabrinervis (asterisk).

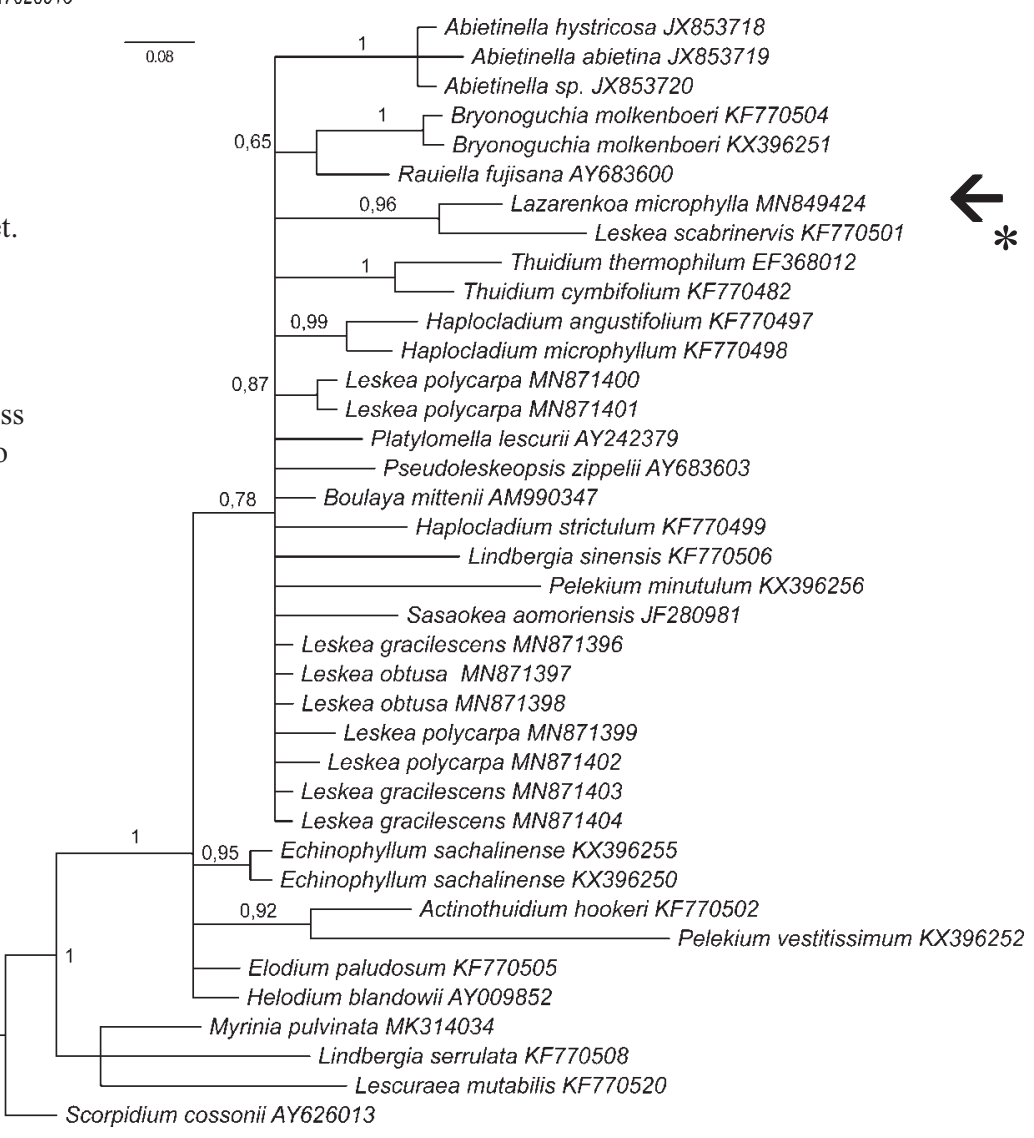




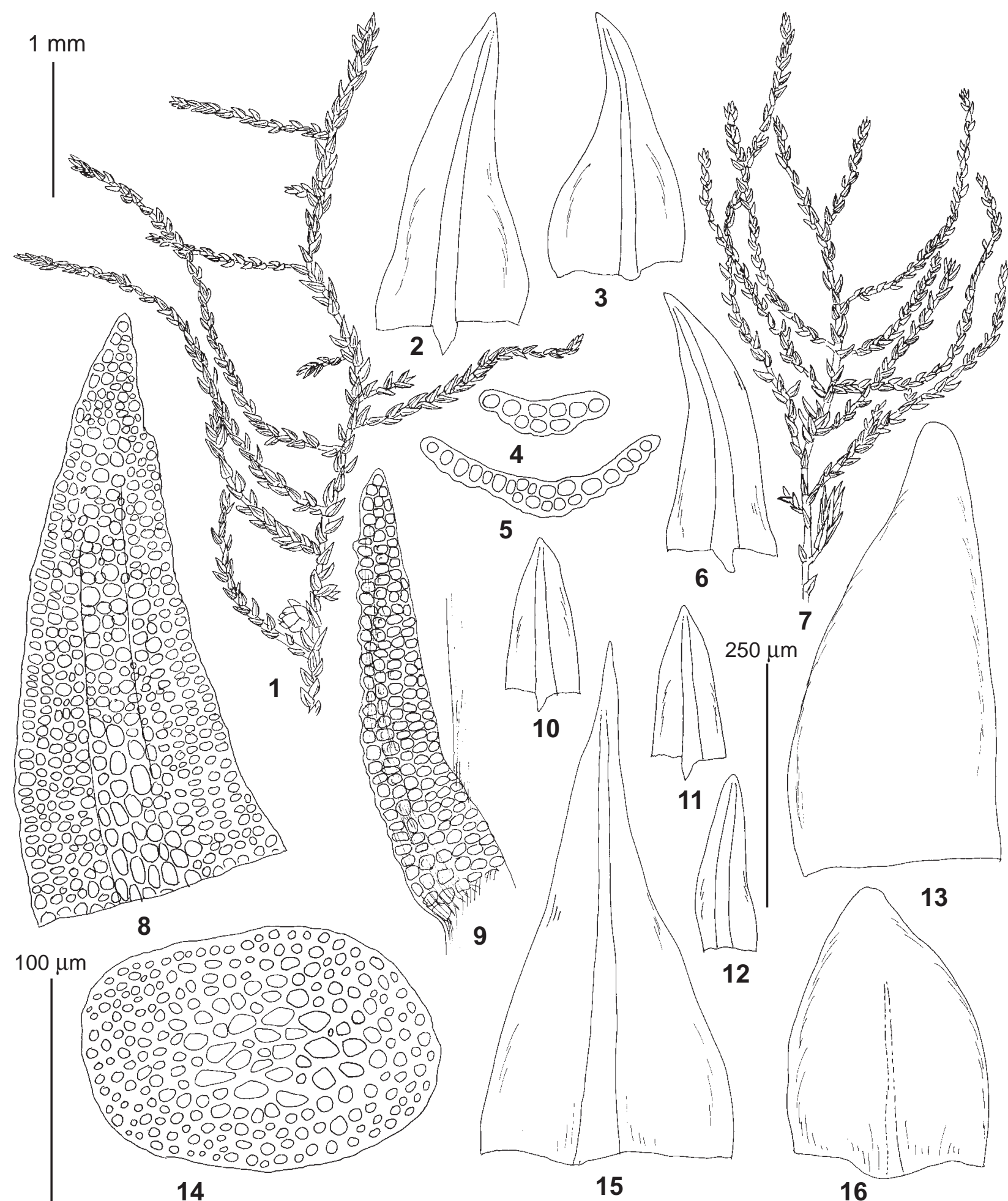

Fig. 4. Lazarenkoa microphylla Ignatov \& Ignatova (from: Russia, Primorsky Territory, 21.IX.2015 Tumurova VL-1-14, UUH, MHA): 1 - habit, dry (male plant); 2-3, 6 - stem leaves; 4-5 - leaf transverse sections; 7 - habit, dry (female plant); 8 - cell areolation of whole stem leaf; 9 - branch leaf; 10-12 - branch leaves; 13, 16 - perigonial leaves; 14 - stem transverse section; 15 - perichaetial leaf. Scale bars: $1 \mathrm{~mm}$ for 1,$7 ; 250 \mu \mathrm{m}$ for $2-3,6,10-13,15-16 ; 100 \mu \mathrm{m}$ for $4-5,8-9,14$.

$0.20 \times 0.05-0.10 \mathrm{~mm}$, (the smaller leaves of $100 \times 50 \mu \mathrm{m}$ being 18 cells along the margin and 9 cells wide); costa 20-50 $\mu \mathrm{m}$ wide at base, occupying 1/3-1/6 the leaf base, ending shortly below the apex; margins entire to slightly and irregularly crenulate at places; leaf cells throughout the lamina isodiametric to oblate, 5-8 $\mu \mathrm{m}$, thick-walled, with low bulgings on dorsal surface, so leaf dorsal side at lateral view looks rough. Dioicous? Inner perichaetial leaves triangular, $0.5 \times 0.25 \mathrm{~mm}$, narrowly acute, costa strong, gradually narrowing upwards, ending be- 

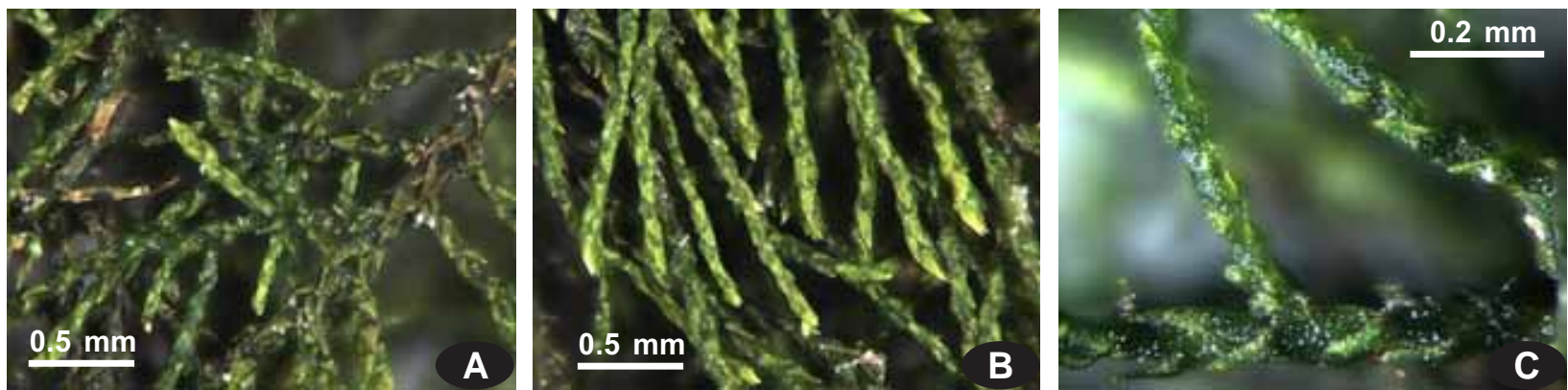

Fig. 5. Lazarenkoa microphylla (from: Russia, Primorsky Territory, 21.IX.2015 Tumurova VL-1-14, UUH, MHA): A: repeatedly branched stem; B: numerous branches on average view of tuft; C: part of branching stem. Photo of dry herbarium specimen.

low apex. Perigonial leaves ovate, $0.3 \times 0.2 \mathrm{~mm}$, blunt to rounded at apex, inner perigonial leaves ecostate. Sporophytes not seen.

Comments on descriptions: The dioicous sexual condition is identified with question mark: all shoots we examined had only one sex (most had no gametangia), however, the plant is copiously branched and so fragile that we admit that the studied male and female shoots grew from the same mother-plants, and we simply failed to find such juntction in the limited material available for study.

Differentiation. Lazarenkoa microphylla is similar to Leskea scabrinervis, which diagnostic characters are also formulated as plants with very small leaves and costa rough at back (Tong et al., 2002). However, leaf size in the latter species is reported as $0.4-1.0 \mathrm{~mm}$ long (Tong et al., 2002), whereas in Lazarenkoa the longest leaf we found was $0.35 \mathrm{~mm}$ long, and many leaves were between 0.10 and $0.15 \mathrm{~mm}$. The difference between the two is also in different nuclear ITS sequences. The latter species is autoicous, although this character of sexual condition is not reliable in this case (see comment on description). Also, according to Tong et al. (2002), Leskea scabrinervis grows on trees, while Lazarenkoa was collected on rocks in temporary stream bed. This type of habitat calls for comparison with North American Platylomella lescurii, which was found to be related to Leskea scabrinervis by Qi-Ying et al. (2019) in molecular phylogenetic analysis. Platylomella is only slightly larger than Leskea scabrinervis, but it has bistratose leaf margins, very different lamina areoaltion of cells with angulate lumina, curved capsule, and apparent autoicous sexual condition (Christy, 2014).

In any case, neither Lazarankoa, nor Leskea scabrivervis do not belong to the genus Leskea, which is well delimited in molecular phylogenetic tree (Figs. 2-1), and has clearly papillose laminal cells.

\section{ACKNOWLEDGEMENTS}

The work of O.D. Dugarova was conducted under the institutional project AAAA-A17-117011810036-3 and field work was supported by RFBR 14-04-01420. Molecular study was supported by RSF18-14-00121.

\section{LITERATURE CITED}

[BARDUNOV, L.V. \& V.Ya. CHERDANTSEVA] БАРДУНОВ Л.В., В.Я. ЧЕРДАНЦЕВА. 1982. Листостебельные мхи Южного Приморья. - [Mosses of the South of Primorskij Province] Новосибирск, Наука [Novosibirsk, Nauka], $208 \mathrm{pp}$.

CHERDANTSEVA, V.YA., O.YU. PISARENKO, M.S. IGNATOV, E.A. IGNATOVA, V.E. FEDOSOV, S.V. DUDOV \& V.A. BAKALIN. 2018. Mosses of the southern Russian Far East, an annotated check-list. Botanica Pacifica 7(2): 53-81.

CHRISTY, J. A. 2014. Limbella, Platylomella. - In: Flora of North America Editorial Committee (eds.). Flora of North America Vol. 28. Oxford University Press, New York, 317-319.

GARDINER, A., M. IGNATOV, S. HUTTUNEN \& A. TROITSKY. 2005. On resurrection of the families Pseudoleskeaceae Schimp. and Pylaisiaceae Schimp. (Musci, Hypnales). - Taxon 54: 651-663.

GOLOBOFF, P. A. 1994. NONA: A Tree Searching Program. - Tucumán, Argentina: Program and documentation, published by the author.

HALL, T.A. 1999. BioEdit: a user-friendly biological sequence alignment editor and analysis program for Windows 95/98/NT. - Nuclear Acids Symposium Series 41: 95-98.

HUELSENBECK, J., \& F RONQUIST. 2001. MRBAYES: Bayesian inference of phylogenetic trees. - Bioinformatics 17: 754-755.

IGNATOV, M.S., E.A. IGNATOVA \& E.V. MALASHKINA. 2013. Ephemerum spinulosum Bruch \& Schimp. (Bryophyta), a new species for Russia. - Arctoa 22: 97-100.

[LAZARENKO, A.S.] ЛАЗАРЕНКО А.С. 1940. Листяні мохи Радянського Далекого Сходу. 1. - [Mosses of the Soviet Far East. 1IV]. Ботанический Журнал АН УРСР [Botanizheskij Zhurnal Akad. Nauk Ukr. RSR] 1(3-4): 59-100.

[LAZARENKO, A.S.] ЛАЗАРЕНКО А.С. 1941а. Листяні мохи Радянського Далекого Сходу. 2. - [Mosses of the Soviet Far East. 2IV]. Бот. Журн. АН УРСР Ботанический Журнал АН УРСР [Botanizheskij Zhurnal Akad. Nauk Ukr. RSR] 2(1): 51-95.

[LAZARENKO, A.S.] ЛАЗАРЕНКО А.С. 1941b. Листяні мохи Радянського Далекого Сходу. 3. - [Mosses of the Soviet Far East. 3] Бот. Журн. АН УРСР Ботанический Журнал АН УРСР [Botanizheskij Zhurnal Akad. Nauk Ukr. RSR] 2(2): 271-308.

[LAZARENKO, A.S.] ЛАЗАРЕНКО А.С. 1945. Листяні мохи Радянського Далекого Сходу. 4. - [Mosses of the Soviet Far East. 4]. Бот. Журн. АН УРСР Ботанический Журнал АН УРСР [Botanizheskij Zhurnal Akad. Nauk Ukr. RSR] 2(3-4): 185-216.

NIXON, K. C. 1999. Winclada (BETA) ver. 0.9.9. Available at: http:// www.cladistics.com/about_winc.html

QI-YING, C., G. BI-CAI \& F. YAN-MING. 2019. Molecular phylogeny of Chinese Thuidiaceae with emphasis on Thuidium and Pelekium. Manuscript avaialble at https://arxiv.org/abs/1902.06032 and https:// arxiv.org/ftp/arxiv/papers/1902/1902.06032.pdf

TONG, C., S. JUN \& G. CHIEN. 2002. Leskeaceae. $-I n: W u, P .-C . \& M$. R. Crosby (eds.) Moss flora of China, English version. Vol. 6. Hookeriaceae-Thuidiaceae, Science Press \& Missouri Botanical Garden, Beijing, New York \& St. Louis. 99-130. 